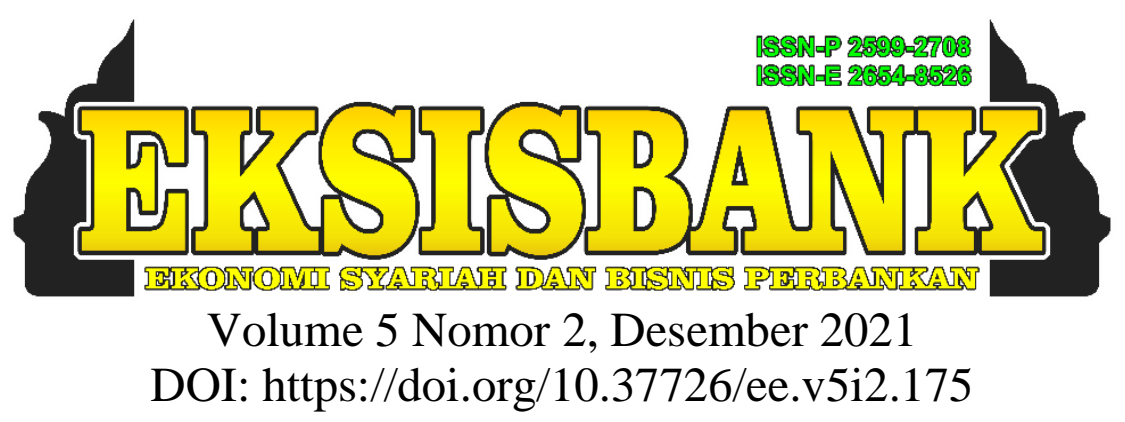

\title{
Pengaruh Pendapatan Operasional Terhadap Laba Bersih pada Bank Muamalat Indonesia Tbk. Periode 2015-2020
}

\author{
Evita Septiani Jaenab ${ }^{1}$, Ghina Fatimatuzzahro ${ }^{2}$, Salsabila Gita Tsanya ${ }^{3}$, R. Deden Adhianto ${ }^{4}$ \\ 1,2,3,4 Administrasi Keuangan Politeknik Piksi Ganesha, Bandung, Indonesia \\ Jl. Jend Gatot Subroto 301, Bandung 40274 \\ ${ }^{1}$ xia6.evitaseptiani@gmail.com \\ 22ghinafatimaa2@gmail.com \\ ${ }^{3}$ salsabilagita976@gmail.com \\ 4adhiantogd@yahoo.com
}

\begin{abstract}
ABSTRAK
Kondisi kinerja keuangan Bank Muamalat Indonesia yang semakin menurun dari tahun ke tahun dikarenakan laba tahun berjalan, modal, aset yang menurun, tingkat pembiayaan macet meningkat dan permasalahan lainnya. Tujuan penelitian ini adalah untuk mengetahui pengaruh Pendapatan Operasional terhadap Laba Bersih pada Bank Muamalat Indonesia Tbk. Periode 2015 sampai dengan tahun 2020. Metode penelitian yang digunakan adalah metode kuantitatif asosiatif dengan menggunakan data sekunder yang berupa laporan keuangan Bank Muamalat Indonesia yang terdaftar secara umum di Otoritas Jasa Keuangan. Pengujian hipotesis menggunakan analisis regresi linear sederhana melalui uji t dengan maksud untuk mengetahui pengaruh variabel independen terhadap variabel dependen. Hasil penelitian ini variabel Pendapatan Operasional terhadap Laba Bersih memiliki nilai korelasi atau hubungan (R) sebesar 0,856 (Sangat Kuat), dan nilai Koefisien Determinasi atau R Square sebesar 0,732 dengan kata lain pengaruhnya 73,2\%, artinya variabel X (Pendapatan Operasional) berpengaruh terhadap variabel Y (Laba Bersih) di Bank Muamalat Indonesia Tbk. Sedangkan sisanya 26,8\% ditentukan oleh variabel lain yang tidak diteliti oleh peneliti yaitu Pendapatan Non Operasional. Adapun hasil penelitian ini memperkuat hasil penelitian sebelumnya karena semakin tinggi hasil Pendapatan Operasional, maka semakin tinggi pula Laba Bersih yang diperoleh.
\end{abstract}

Kata kunci - Pendapatan Operasional, Laba Bersih

\section{ABSTRACT}

The condition of Bank Muamalat Indonesia's financial performance which is decreasing from year to year is due to the current year's profit, capital, assets that decrease, the level of non-

EKSISBANK (Ekonomi Syariah dan Bisnis Perbankan), Volume 5, Nomor 2, Desember 2021 
performing financing increases and other problems. The purpose of this study was to determine the effect of operating income on net income at Bank Muamalat Indonesia Tbk. The period 2015 to 2020. The research method used is an associative quantitative method using secondary data in the form of financial statements of Bank Muamalat Indonesia which are publicly registered with the Financial Services Authority. Hypothesis testing using simple linear regression analysis through t-test with a view to knowing the effect of the independent variable on the dependent variable. The results of this study that the Operating Income variable on Net Profit has a correlation value or relationship $(R)$ of 0.856 (Very Strong), and the value of the Coefficient of Determination or $R$ Square of 0.732 in other words the effect is $73.2 \%$, meaning that the variable X (Operational Income) has an effect on the Y variable (Net Profit) at Bank Muamalat Indonesia Tbk. While the remaining $26.8 \%$ is determined by other variables not examined by researchers, namely Non-Operational Income. The results of this study strengthen the results of previous studies because the higher the results of Operating Income, the higher the Net Profit obtained.

Keywords - Operating Income, Net Profit

\section{PENDAHULUAN}

Pada Juli 1997 perbankan Indonesia pernah mengalami krisis moneter yang melanda dunia dan disusul dengan krisis politik nasional yang telah membawa dampak besar bagi perekonomian di Indonesia. Krisis tersebut menyebabkan dampak pada perbankan Indonesia saat ini, didominasi oleh bank konvensional yang mengalami kesulitan penggunaan bunga, meskipun awalnya mampu bergerak dinamis sektor, namun mendorong perbankan menjadikan perekonomian Indonesia mengalami efek pertumbuhan semu yang menyebabkan beberapa bank konvensional akhirnya kritis dan tidak layak beroperasi. Keadaan tersebut menyebabkan pemerintah Indonesia terpaksa mengambil tindakan untuk restrukturisasi sebagian bank di Indonesia.

Salah satu tindakan pemerintah adalah melakukan perubahan Undang-Undang perbankan dengan disahkannya Undang-Undang No.10 tahun 1998 sebagai perubahan Undang Undang No.7 tahun 1992 tentang perbankan telah memberi kesempatan luas untuk pengembangan jaringan perbankan syariah telah menyadarkan semua pihak bahwa perbankan dengan sistem konvensional bukan merupakan satu-satunya sistem yang dapat diandalkan, karena ada sistem perbankan lain yang lebih unggul dengan menawarkan prinsip keadilan dan keterbukaan, yaitu perbankan syariah. (Winarto \& Nuraisyah, 2019)

Bank syariah merupakan lembaga keuangan yang kegiatan usahanya berdasarkan prinsip syariah dengan melaksanakan 3 fungsi utamanya yaitu menghimpun dana dari masyarakat dalam bentuk simpanan, menyalurkan dana kepada masyarakat dalam bentuk pembiayaan, dan sebagai penyedia jasa pelayanan perbankan. Berdasarkan Pasal $4 \mathrm{UU}$ No. 21 Tahun 2008, bank syariah wajib menjalankan fungsinya untuk menghimpun dan menyalurkan dana. Salah satu keberhasilan bank syariah yaitu mendapatkan pendapatan yang optimal sehingga dapat meningkatkan pertumbuhan laba bersih bank syariah. Apabila pendapatan bank meningkat, maka laba bersih yang diperoleh bank juga akan meningkat.

Bank Islam pertama yaitu Bank Muamalat Indonesia. Didirikan pada tahun 1991 dan memulai kegiatan operasionalnya pada bulan Mei 1992. Bank Muamalat Indonesia (BMI) merupakan bank pertama di Indonesia yang mengoperasikan kegiatannya berdasarkan prinsip-prinsip Islam. Sebagai suatu bank, BMI tetap melaksanakan operasionalnya sama dengan bank-bank konvensional lainnya 
selama tidak bertentangan dengan prinsip syariah. BMI tidak terlepas dari usaha-usaha untuk mencapai keuntungan yang akan dibagihasilkan kepada para nasabahnya. Selain itu BMI juga tetap harus berpegangan pada prinsip Prudential Banking, yaitu prinsip kehati-hatian bank dalam mengoperasikan usahanya agar tetap dalam kondisi kinerja yang baik dan memenuhi kriteria bank (Ummah \& Suprapto, 2013).

Kinerja keuangan Bank Muamalat semakin menurun dari tahun ke tahun dikarenakan laba tahun berjalan, modal, aset yang menurun, tingkat pembiayaan macet meningkat dan permasalahan lainnya. Namun, pada tahun 2018 kinerja Bank Muamalat sempat meningkat, hal ini disebabkan karena ditopang oleh dana pendapatan penyaluran dana murabahah, pembiayaan bermasalah turun dan hal lainnya. tetapi pada tahun 2020 mengalami penurunan kembali dikarenakan kualitas aset yang tidak baik, pembenahan kredit bermasalah nasabah yang meningkat akibat pandemi Covid-19 dan penurunan Dana Pihak Ketiga (DPK) akibat kepercayaan masyarakat meletakkan dananya di BMI menurun drastis.

\section{Pendapatan Operasional}

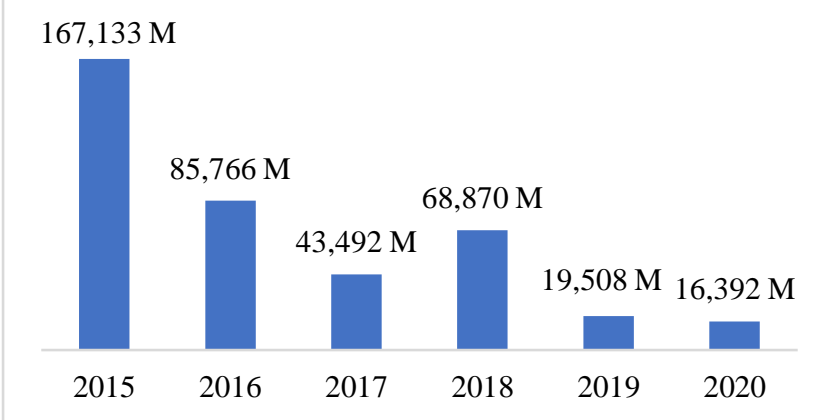

Grafik 1.1 Pendapatan Operasional

Berdasarkan grafik 1.1 menunjukkan bahwa pendapatan operasional yang diperoleh Bank Muamalat Indonesia Tbk. dari tahun
2015 sampai tahun 2020 mengalami penurunan sedikit namun secara terus-menerus. Pada tahun 2015, pendapatan operasional bank sebesar Rp.167,133 Miliar. Pada tahun 2016 dan 2017, mengalami penurunan menjadi Rp.85,766 Miliar dan Rp.43,492 Miliar. Pada tahun 2018, mengalami kenaikan sebesar Rp.68,870 Miliar. Tetapi pada tahun 2019 dan 2020, mengalami penurunan kembali yaitu sebesar Rp.19,508 Miliar dan Rp.16,392 Miliar.

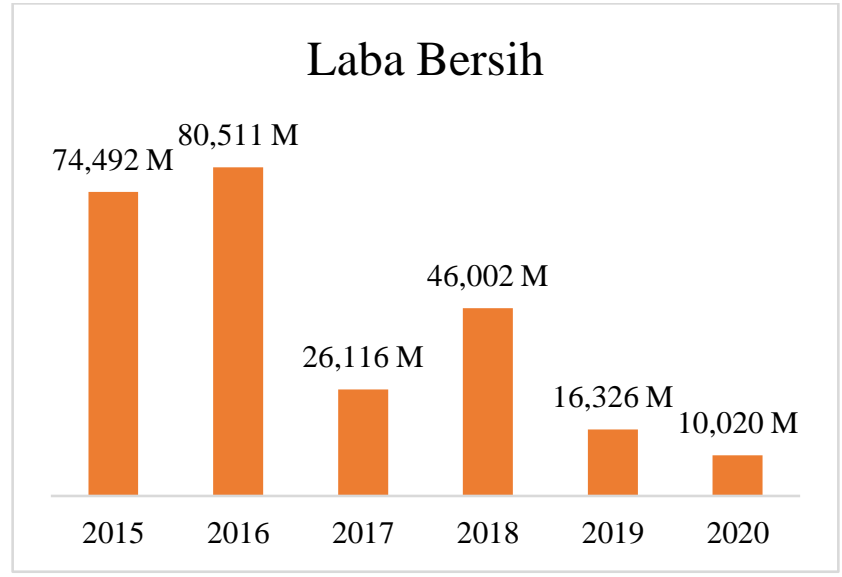

Grafik 1.2 Laba Bersih

Berdasarkan grafik 1.2 menunjukkan adanya peningkatan pada tahun 2015 dan 2016 sebesar Rp.74,492 Miliar dan Rp. 80,511 Miliar, tetapi pada tahun 2017 mengalami penurunan sebesar Rp.26,116 Miliar, sedangkan pada tahun 2018 mengalami kenaikan sebesar Rp.46,002 Miliar. Dan penurunan kembali pada tahun tahun 2019 dan 2020 sebesar Rp.16,326 Miliar dan Rp.10,020 Miliar.

Penulis menemukan beberapa penelitian terdahulu yang membahas topik yang sama dengan penelitian ini. Penelitian yang dilakukan oleh (Nurbatresia, 2021) tentang Pengaruh Pendapatan Operasional dan Pendapatan Non Operasional Terhadap Laba Bersih PT Bank Muamalat Indonesia Tbk. bahwa hasil pengujian hipotesis pertama $\left(\mathrm{H}_{1}\right)$ secara parsial terdapat pengaruh positif dan signifikan antara Pendapatan Operasional terhadap 
Laba Bersih. Penelitian yang dilakukan oleh (Pratama, 2018) tentang Pengaruh Jumlah Pendapatan Operasional Setelah Distribusi Bagi Hasil Dan Beban Operasional Lainnya Terhadap Laba Tahun Berjalan Setelah Pajak Bersih Pada PT. Bank Muamalat Indonesia bahwa Secara parsial Pendapatan Operasional Setelah Distribusi Bagi Hasil berpengaruh positif namun tidak signifikan terhadap Laba Tahun Berjalan Setelah Pajak Bersih (EAT). Penelitian yang dilakukan oleh (Rohmatin, 2015) tentang Pengaruh Beban Operasional Pendapatan Operasional, dan Rasio Kecukupan Modal terhadap Pertumbuhan Laba Bank Muamalat Indonesia Periode 2012-2014 bahwa variabel Beban Operasional Pendapatan Operasional (BOPO) berpengaruh positif dan tidak signifikan terhadap variabel Pertumbuhan Laba Bersih Bank Muamalat Indonesia.

Berdasarkan kondisi kinerja keuangan Bank Muamalat Indonesia yang semakin menurun dari tahun ke tahun dan fenomena hasil penelitian terdahulu yang telah dilakukan oleh peneliti sebelumnya dengan rumusan masalah berdasarkan latar belakang yang diteliti yaitu Bagaimana Pendapatan Operasional, Laba Bersih dan Apakah ada pengaruh antara kedua variabel tersebut pada Bank Muamalat Tbk. Perode 2015-2020. Berdasarkan hal tersebut membuat peneliti tertarik untuk menguji mengenai pengaruh pendapatan operasional terhadap laba ber-sih, maka peneliti mengambil judul "Pengaruh Pendapatan Operasional terhadap Laba Bersih pada Bank Muamalat Indonesia Tbk. Periode 2015-2020". Penelitian ini bertujuan untuk mengetahui Pengaruh Pendapatan Operasional terhadap Laba Bersih pada Bank Muamalat Indonesia Tbk. Periode 2015 sampai dengan 2020.

\section{TINJAUAN PUSTAKA \\ A. Kajian Teori}

\section{Pendapatan}

Pendapatan adalah arus masuk bruto manfaat ekonomi yang timbul dari aktivitas normal perusahaan selama periode yang mengakibatkan kenaikan ekuitas, yang tidak termasuk dari kontribusi penanaman modal. Pendapatan hanya terdiri dari arus masuk bruto manfaat ekonomi yang diterima oleh perusahaan untuk dirinya sendiri. Jumlah yang ditagih untuk dan atau atas nama pihak ketiga bukan merupakan pendapatan karena tidak menghasilkan manfaat ekonomi bagi perusahaan dan tidak mengakibatkan kenaikan ekuitas (PSAK No. 23, 2018).

Pendapatan yang diterima oleh bank terdiri dari pendapatan operasional dan non operasional. Pendapatan operasional diperoleh bank dari pendapatan bunga debitur, pendapatan komisi dan provisi, pendapatan atas transaksi valuta asing, dan pendapatan operasional lain (deviden, penjualan surat berharga). Sedangkan pendapatan non operasional diperoleh bank dari penjualan aktiva tetap dan pendapatan dari penyewaan fasilitas gedung yang dimiliki oleh bank (Rozali \& Tjondro, 2013).

Dalam penelitian ini, pendapatan yang digunakan adalah pendapatan usaha. Pendapatan usaha adalah laba dari semua aktivanya, dengan mengabaikan apakah aktiva tersebut dibiayai dari saham atau hutang. Adapun rumus pendapatan yaitu hasil penjumlahan dari Pendapatan Operasi ditambah Pendapatan non-operasi (Kartini, 2017).

\section{Laba Bersih}

Laba bersih adalah selisih lebih pendapatan atas beban-beban dan merupakan kenaikan bersih atas modal yang berasal dari kegiatan usaha" (Rachman \& Putri, 2019). 
Laba bersih berasal dari transaksi pendapatan, beban, perusahaan dagang, maupun perusahaan manufaktur (Manda, 2018).

Laba bersih merupakan selisih positif antara total pendapatan dengan total biaya, sehingga besarnya jumlah laba yang diperoleh perusahaan tergantung kepada kedua pos tersebut (Wida et al., 2019).

Laba bersih (net profit) adalah laba yang telah dikurangi biaya-biaya perusahaan dalam suatu periode tertentu termasuk pajak (Suhaemi \& Hasanuh, 2021).

Dari pengertian di atas dapat disimpulkan bahwa laba bersih adalah kelebihan seluruh pendapatan atas seluruh biaya untuk seluruh periode tertentu setelah dikurangi pajak penghasilan yang disajikan dalam laporan laba rugi.

Bank yang sehat akan dapat melakukan kinerja yang baik dan menghasilkan laba yang optimal. Pertumbuhan laba yang optimal mencerminkan sistem yang terdapat didalamnya berjalan dengan efektif dan efisien (Supeno, 2019).

Tujuan pelaporan laba mempunyai tujuan utama dan tujuan khusus. Tujuan utama pelaporan laba adalah untuk memberikan informasi yang berguna bagi mereka yang berkepentingan dengan laporan keuangan. Sedangkan tujuan khusus pelaporan laba adalah sebagai berikut:

1. Penggunaan laba sebagai pengukuran efektivitas manajemen.

2. Penggunaan laba sebagai historis untuk membantu meramalkan keadaan usaha dan distribusi deviden di masa yang akan datang.

3. Penggunaan laba sebagai pengukur keberhasilan serta pedoman pengambilan keputusan manajemen masa yang akan datang.

4. Penggunaan laba sebagai dasar pengenaan pajak.
5. Penggunaan laba sebagai dasar pengawasan perusahaan yang berhubungan dengan kepentingan umum (Nalsal \& Widyawati, 2015).

\section{Bank Syariah}

Bank merupakan lembaga perantara keuangan (financial intermediaries) yang menyalurkan dana dari pihak kelebihan dana (surplus unit) kepada pihak yang membutuhkan dana (defisit unit) pada waktu yang ditentukan (Suryadi et al., 2020).

Di dalam Undang-Undang No. 7 Tahun 1992 Tentang Perbankan sebagaimana telah diubah dengan Undang-Undang No. 10 Tahun 1998 disebutkan bahwa Bank adalah badan usaha yang menghimpun dana dari masyarakat dalam bentuk simpanan dan menyalurkannya kepada masyarakat dalam bentuk kredit dan atau bentuk-bentuk lainnya dalam rangka meningkatkan taraf hidup rakyat banyak.

Saat ini perbankan di Indonesia sedang mengalami perkembangan yang sangat signifikan, seiring dengan berkembangnya pemikiran masyarakat tentang sistem perbankan syariah yang tanpa bunga (riba). Bank di Indonesia terbagi menjadi dua, yaitu bank syariah dan bank konvensional. Menurut Undang-Undang Nomor 21 tahun 2008 tentang Perbankan Syariah dalam pasal 1 menjelaskan bahwa Bank Konvensional adalah bank yang menjalankan kegiatan usahanya secara konvensional dan berdasarkan jenisnya terdiri atas Bank Umum Konvensional dan Bank Perkreditan Rakyat, sedangkan Bank Syariah adalah Bank yang menjalankan kegiatan usahanya berdasarkan prinsip syariah dan menurut jenisnya terdiri atas Bank Umum Syariah dan Bank Pembiayaan Rakyat Syariah (Romdhoni \& Yozika, 2018).

Bank Syariah adalah bank yang dalam aktivitasnya, baik penghimpunan dana maupun 
dalam rangka penyaluran dananya memberikan dan mengenakan imbalan atas dasar prinsip syariah yaitu jual beli dan bagi hasil. Bank Syariah menjalankan kegiatan usahanya berdasarkan prinsip syariah dan menjauhi praktek riba untuk diisi dengan kegiatan investasi atas dasar bagi hasil dari pembiayaan perdagangan. Industri perbankan syariah merupakan bagian dari sistem perbankan nasional yang mempunyai peranan penting dalam perekonomian Peranan perbankan syariah secara khusus antara lain sebagai perekat nasionalisme baru artinya menjadi fasilitator jaringan usaha ekonomi kerakyatan, memberdayakan ekonomi umat, mendorong penurunan spekulasi di pasar keuangan, mendorong pemerataan pendapatan dan peningkatan efisiensi mobilitas dana (Hartini, 2016).

Pada tahun 1992 Bank Muamalat Indonesia berdiri sebagai tanda dimulainya dual definisi Bank, Bank Umum dan Bank Perkreditan Rakyat dalam Undang-Undang Nomor 10 Tahun 1998 Pasal 1 tentang perbankan (Marimin \& Romdhoni, 2017).

Bank Muamalat berdiri sebagai bank syariah pertama yang kemudian bank-bank konvensional diperkenankan membuka kantor layanan syariah yang mana sekarang ini sudah banyak bank dan semakin berkembang dengan adanya permintaan masyarakat akan adanya jasa tabungan atau pembiayaan/ kredit tanpa bunga (Romdhoni \& Yozika, 2018).

\section{B. Perbandingan Penelitian Terdahulu}

Penelitian tentang Pengaruh Pendapatan Operasional terhadap Laba Bersih pada Bank Muamalat Indonesia Tbk., sudah banyak dilakukan penelitian oleh peneliti sebelumnya, seperti penelitian-penelitian sebagai berikut:

1. Pendapatan Usaha dan Beban Operasional terhadap Laba Bersih pada Perusahaan Makanan dan Minuman (Pasaribu Masdiana, 2017)
Hasil penelitian ini secara parsial menunjukkan bahwa pendapatan usaha memiliki pengaruh postif terhadap laba bersih. Sedangkan Beban operasional tidak berpengaruh terhadap laba bersih. Sedangkan secara simultan, hasil penelitian ini menunjukkan bahwa variabel pendapatan usaha dan beban operasional secara simultan berpengaruh terhadap laba bersih.

Dari penelitian ini terdapat perbedaan dengan penelitian terdahulu yaitu penelitian saat ini meneliti tentang Pengaruh Pendapatan Operasional terhadap Laba Bersih pada Bank Muamalat Indonesia Tbk. Sedangkan penelitian terdahulu meneliti tentang Pendapatan Usaha dan Beban Operasional terhadap Laba Bersih pada Perusahaan Makanan dan Minuman. Adapun persamaannya yaitu meneliti pengaruh pendapatan operasional terhadap laba bersih.

2. Pengaruh Pendapatan Usaha dan Beban Operasional terhadap Laba Bersih pada Perusahaan Tekstil dan Garmen yang Terdaftar di Bursa Efek Indonesia Periode Tahun 2013-2017 (Sa'diya et al., 2019)

Hasil Uji Hipotesis secara parsial menunjukkan bahwa Pendapatan Usaha mempunyai pengaruh positif signifikan terhadap Laba Bersih Perusahaan Tekstil dan Garmen, artinya adalah bahwa semakin tinggi Pendapatan Usaha maka akan dapat meningkatkan Laba Bersih, dan sebaliknya jika Pendapatan Usaha menurun maka akan dapat menurunkan Laba Bersih, sehingga dapat ditarik simpulan bahwa hipotesis yang diajukan dalam penelitian ini terbukti atau dapat diterima. Sedangkan hasil Uji Hipotesis secara parsial menunjukkan bahwa Beban Operasional tidak mempunyai pengaruh signifikan terhadap Laba Bersih Perusahaan Tekstil dan Garmen.

Dari penelitian ini terdapat perbedaan dengan penelitian terdahulu yaitu penelitian 
saat ini meneliti tentang Pengaruh Pendapatan Operasional terhadap Laba Bersih pada Bank Muamalat Indonesia Tbk. Sedangkan penelitian terdahulu meneliti tentang Pengaruh Pendapatan Usaha dan Beban Operasional terhadap Laba Bersih pada Perusahaan Tekstil dan Garmen yang Terdaftar di Bursa Efek Indonesia Periode Tahun 20132017. Adapun persamaannya yaitu meneliti pengaruh pendapatan operasional terhadap laba bersih.

\section{Pengaruh Pendapatan Dan Biaya} Operasional Terhadap Laba Bersih Studi Kasus Pada Pt. Garuda Indonesia Tbk. (Wulandari, 2017)

Hasil dari penelitian tersebut adalah untuk mengetahui bagaimana pengaruh Pendapatan dan Biaya Operasional baik secara simultan maupun parsial terhadap Laba Bersih. Data yang diambil berupa data sekunder yang diambil melalui Laporan Keuangan yaitu Laporan Laba-Rugi periode 2006-2015. Dalam analisis regresi berganda yang dilakukan, diperoleh hasil bahwa terdapat hubungan yang positif antara Pendapatan dengan Laba Bersih. Dan terdapat hubungan yang negatif antara Biaya Operasional dengan Laba Bersih. Dan perhitungan uji hipotesis baik uji $\mathrm{F}$ dan uji t menunjukkan bahwa secara simultan Pendapatan dan Biaya Operasional berpengaruh terhadap Laba Bersih dengan tingkat signifikansi di bawah 5\%. Di samping itu, secara parsial Pendapatan berpengaruh terhadap Laba Bersih, dan secara parsial juga Biaya Operasional berpengaruh terhadap Laba Bersih dengan tingkat signifikansi di bawah $5 \%$. Perusahaan pemerintah terutama PT. Garuda Indonesia yang menjadi sampel pada penelitian ini harus mengendalikan dengan baik pendapatan dan biaya operasional. Karena komposisi dari laporan laba rugi baik pendapatan dan biaya operasional dapat menjadi menguntungkan mendapatkan laba bersih atau bahkan merugikan bagi perusahaan.

Dari penelitian ini terdapat perbedaan dengan penelitian terdahulu yaitu penelitian saat ini meneliti tentang Pengaruh Pendapatan Operasional terhadap Laba Bersih pada Bank Muamalat Indonesia Tbk. Sedangkan penelitian terdahulu meneliti tentang Pengaruh Pendapatan Dan Biaya Operasional Terhadap Laba Bersih Studi Kasus Pada Pt. Garuda Indonesia Tbk. Adapun persamaannya yaitu meneliti pengaruh pendapatan operasional terhadap laba bersih.

4. Pengaruh Pendapatan Usaha dan Biaya Operasional terhadap Laba Bersih Survey pada Perusahaan Jasa Sub Sektor Transportasi yang Terdaftar di Bursa Efek Indonesia (Pasca, 2019)

Berdasarkan uji hipotesis dapat disimpulkan bahwa terdapat pengaruh yang signifikan antara Pendapatan Usaha dan Biaya Operasional terhadap Laba Bersih pada perusahaan jasa sub sektor transportasi yang terdaftar di Bursa Efek Indonesia periode tahun 2013-2017. Dimana pendapatan usaha dan biaya operasional mempunyai hubungan dengan laba bersih yang sangat kuat dan berbanding lurus, artinya ketika pendapatan usaha dan biaya operasional meningkat maka laba bersih pun akan mengalami peningkatan.

Dari penelitian ini terdapat perbedaan dengan penelitian terdahulu yaitu penelitian saat ini meneliti tentang Pengaruh Pendapatan Operasional terhadap Laba Bersih pada Bank Muamalat Indonesia Tbk. Sedangkan penelitian terdahulu meneliti tentang Pengaruh Pendapatan Usaha dan Biaya Operasional terhadap Laba Bersih Survey pada Perusahaan Jasa Sub Sektor Transportasi 
yang Terdaftar di Bursa Efek Indonesia. Adapun persamaannya yaitu meneliti pengaruh pendapatan operasional terhadap laba bersih.

5. Pengaruh Pendapatan Usaha Dan Biaya Operasional Terhadap Laba Bersih Pada Perusahaan Manufaktur Sub Sektor Logam Dan Sejenisnya Yang Terdaftar Di Bursa Efek Indonesia Periode 2014-2018 (Rahmawati \& Kosasih, 2020)

Penelitian tersebut bertujuan untuk mengetahui pendapatan usaha, biaya operasional, laba bersih, pengaruh pendapatan usaha terhadap laba bersih, pengaruh biaya operasional terhadap laba bersih serta pengaruh pendapatan usaha dan biaya operasional terhadap laba bersih pada perusahaan manufaktur sub sektor logam dan sejenisnya yang terdaftar di Bursa Efek Indonesia periode 2014-2018. Metode yang digunakan dalam penelitian ini adalah deskriptif dan verifikatif dengan pendekatan kuantitatif. Sampel berjumlah 30 diperoleh dari laporan laba rugi 6 perusahaan per tahun 2014-2018. Statistik deskriptif, analisis regresi linier berganda, koefisien determinasi dan pengujian hipotesis adalah metode statistik yang digunakan. Dari hasil penelitian ini diketahui bahwa pendapatan usaha berfluktuatif dan cenderung meningkat, biaya operasional berfluktuatif dan cenderung meningkat, laba bersih berfluktuatif dan cenderung menurun, pendapatan usaha tidak berpengaruh terhadap laba bersih, biaya operasional berpengaruh terhadap laba bersih, pendapatan usaha dan biaya operasional berpengaruh secara simultan terhadap laba bersih.

Dari penelitian ini terdapat perbedaan dengan penelitian terdahulu yaitu penelitian saat ini meneliti tentang Pengaruh Pendapatan Operasional terhadap Laba Bersih pada Bank Muamalat Indonesia Tbk. Sedangkan penelitian terdahulu meneliti tentang Pengaruh Pendapatan Usaha Dan Biaya Operasional Terhadap Laba Bersih Pada Perusahaan Manufaktur Sub Sektor Logam Dan Sejenisnya Yang Terdaftar Di Bursa Efek Indonesia Periode 2014-2018. Adapun persamaannya yaitu meneliti pengaruh pendapatan operasional terhadap laba bersih.

\section{METODOLOGI PENELITIAN}

Pendekatan penelitian yang digunakan dalam penelitian ini adalah penelitian kuantitatif. Menurut (Sugiyono, 2015), metode penelitian kuantitatif dapat diartikan sebagai metode penelitian yang berlandaskan pada filsafat positivism, yang digunakan untuk meneliti pada populasi atau sampel tertentu, teknik pengambilan sampel pada umumnya dilakukan secara random, pengumpulan data menggunakan instrumen penelitian, analisis data bersifat kuantitatif atau statistik dengan tujuan untuk menguji hipotesis yang telah ditetapkan.

Jenis penelitian yang digunakan adalah penelitian asosiatif, yaitu penelitian untuk mengetahui apakah terdapat pengaruh atau hubungan antara variabel bebas (independent variable) dengan variabel terikat (dependent variable) (Wahyuni, 2016).

Populasi dalam penelitian ini adalah Bank Muamalat Indonesia. Teknik pengambilan sampel dalam penelitian ini menggunakan metode secara purposive sampling yaitu metode dimana pemilihan sampel pada karakteristik populasi yang sudah diketahui sebelumnya dengan kriteria sebagai berikut:

a. Bank Muamalat Indonesia merupakan Bank Umum Syariah.

b. Bank Muamalat Indonesia tersebut membuat laporan keuangan triwulan pada periode 2015-2020 dan telah dipublikasikan oleh Bank Indonesia.

EKSISBANK (Ekonomi Syariah dan Bisnis Perbankan), Volume 5, Nomor 2, Desember 2021 http://journal.sties-purwakarta.ac.id/index.php/EKSISBANK/ 
c. Data untuk penelitian tersedia antara tahun 2015-2020 dalam bentuk laporan keuangan triwulan.

Sumber data dalam penelitian ini adalah data sekunder. Menurut (Sugiyono, 2015) data sekunder adalah "sumber data yang tidak langsung memberikan data kepada pengumpul data, misalnya lewat orang lain atau lewat dokumen". Data penelitian ini berupa laporan keuangan Bank Muamalat Indonesia yang terdaftar secara umum di Otoritas Jasa Keuangan.

Metode pengumpulan data dalam penelitian ini adalah dengan metode dokumentasi, yaitu suatu penelitian yang dilakukan dengan cara mencatat atau mendokumentasikan data yang sudah ada.

Teknik analisis data yang dilakukan yaitu analisis statistik deskriptif (uji normalitas), analisis regresi linier sederhana, koefisien determinasi dan uji t (uji signifikan parameter individual).

\section{HASIL DAN PEMBAHASAN A. Hasil Uji Statistik}

Berdasarkan data laporan keuangan yang diperoleh dari Otoritas Jasa Keuangan (OJK) selama periode 2015-2020 menunjukkan hasil:

1. Uji Statistik

Tabel 4.1

Hasil Uji Kolmogorov-Smirnov Test One-Sample Kolmogorov-Smirnov Test

\begin{tabular}{|c|c|c|}
\hline & & $\begin{array}{l}\text { Unstandardized Re- } \\
\text { sidual }\end{array}$ \\
\hline \multicolumn{2}{|l|}{$\mathrm{N}$} & 6 \\
\hline \multirow[b]{2}{*}{ Normal Parameters ${ }^{\mathrm{a}, \mathrm{b}}$} & Mean & $0 \mathrm{E}-7$ \\
\hline & $\begin{array}{l}\text { Std. Devia- } \\
\text { tion }\end{array}$ & 15505,13935259 \\
\hline \multirow{3}{*}{ Most Extreme Differences } & Absolute & ,276 \\
\hline & Positive & 276 \\
\hline & Negative &,- 191 \\
\hline Kolmogorov-Smirnov Z & &, 675 \\
\hline Asymp. Sig. (2-tailed) & & ,752 \\
\hline
\end{tabular}

Berdasarkan tabel 4.1 diatas dari hasil uji one sample Kolmogorov-smirnov diatas dapat diketahui bahwa nilai signifikansi Asymp.Sig menunjukkan angka 0,752. Karena signifikansi lebih dari $0,05(0,752>0,05)$ maka nilai residual telah berdistribusi normal.

2. Uji Autokorelasi

Tabel 4.2

Model Summary

\begin{tabular}{|l|r|r|r|r|r|}
\hline \begin{tabular}{|l} 
Mode \\
1
\end{tabular} & R & R Square & $\begin{array}{r}\text { Adjusted } \\
\text { R Square }\end{array}$ & $\begin{array}{c}\text { Std. Error } \\
\text { of the Esti- } \\
\text { mate }\end{array}$ & $\begin{array}{r}\text { Durbin- } \\
\text { Watson }\end{array}$ \\
\hline 1 &, $856^{\mathrm{a}}$ &, 732 &, 665 & 17335,273 & 2,695 \\
\hline
\end{tabular}

Berdasarkan tabel 4.2 diatas menjelaskan besarnya nilai korelasi atau hubungan (R) sebesar 0,856 (Sangat Kuat), sedangkan Koefisien Determinasi $\left(\mathrm{R}^{2}\right.$ atau $\mathrm{R}$ Square = besarnya pengaruh variabel Pendapatan Operasional Terhadap Laba Bersih) sebesar 0,732 dengan kata lain pengaruhnya $73,2 \%$ sisanya dipengaruhi oleh variabel lain yaitu Pendapatan Non Operasional.

\section{Analisis Regresi Linier Sederhana} Tabel 4.3

Hasil Analisis Regresi

\begin{tabular}{|c|c|c|c|c|}
\hline \multicolumn{5}{|c|}{ Coefficients $^{\mathrm{a}}$} \\
\hline \multirow{2}{*}{\multicolumn{2}{|c|}{ Model }} & \multicolumn{2}{|c|}{$\begin{array}{l}\text { Unstandardized Coeffi- } \\
\text { cients }\end{array}$} & \multirow{2}{*}{$\begin{array}{c}\text { Standardized } \\
\text { Coefficients } \\
\text { Beta }\end{array}$} \\
\hline & & $\mathrm{B}$ & Std. Error & \\
\hline & (Constant) & 11703,617 & 11634,900 & \\
\hline 1 & $\begin{array}{l}\text { Pendapatan } \\
\text { Operasional }\end{array}$ & ,457 & ,138 & ,856 \\
\hline
\end{tabular}

a. Dependent Variable: Laba Bersih

Berdasarkan tabel 4.3 pada kolom B Konstan (a) adalah 11703,617. Sedangkan nilai modal sendiri (b) sebesar 0,457. Sehingga Persamaan Regresinya dapat ditulis:

$$
\mathrm{Y}=\mathrm{a}+\mathrm{bX} \text { atau } \mathrm{Y}=11703,617+0,457 \mathrm{X}
$$


Koefisien $\mathrm{b}$ disebut sebagai koefisien arah regresi, yang menunjukkan perubahan ratarata variabel Y (Laba Bersih) untuk setiap perubahan satu satuan dari Variabel X (Pendapatan Operasional). Perubahan akan positif (menambah) jika b bertanda positif, sebaliknya perubahan akan negatif (menurun) jika $b$ bertanda negatif. Penjelasan dari persamaan di atas:

a. Jika konstanta sebesar 11703,617 dan jika nilai X (Pendapatan Operasional) 0, artinya tidak ada Pendapatan Operasional, maka dapat dikatakan nilai Laba Bersih sebesar Rp. 11703,617.

b. Koefisien regresi $\mathrm{X}$ sebesar 0,457 menyatakan bahwa setiap penambahan satuan nilai Pendapatan Operasional akan memperoleh Laba Bersih 0,457.

\section{Uji t}

\begin{tabular}{|c|c|c|c|}
\hline & $\begin{array}{c}\text { Tabel } \\
\text { Hasil } \\
\text { Coeffic }\end{array}$ & & \\
\hline \multicolumn{2}{|c|}{ Model } & $\mathrm{t}$ & Sig. \\
\hline \multirow{2}{*}{1} & (Constant) & 1,006 &, 371 \\
\hline & Pendapatan Operasional & 3,307 &, 030 \\
\hline
\end{tabular}

a. Dependent Variable: Laba Bersih

Berdasarkan tabel 4.4 diatas diketahui Pendapatan Operasional memiliki nilai sebesar 3,307 dan nilai signifikannya $0,030<0,05$, maka Ho ditolak dan $\mathrm{H} 1$ diterima. Ini menjelaskan ada pengaruh signifikan (nyata) variabel Pendapatan Operasional terhadap variabel Laba Bersih.

\section{B. Pembahasan}

Pengaruh Pendapatan Operasional terhadap Laba Bersih pada Bank Muamalat Indonesia Tbk. Berdasarkan hasil uji one sample Kolmogorov-smirnov dapat diketahui bahwa nilai signifikansi Asymp.Sig menunjukkan angka 0,752. Karena signifikansi lebih dari
$0,05(0,752>0,05)$ maka nilai residual telah berdistribusi normal.

Berdasarkan nilai korelasi atau hubungan (R) sebesar 0,856 (Sangat Kuat), sedangkan Koefisien Determinasi $\left(\mathrm{R}^{2}\right.$ atau $\mathrm{R}$ Square = besarnya pengaruh variabel Pendapatan Operasional Terhadap Laba Bersih) sebesar 0,732 dengan kata lain pengaruhnya $73,2 \%$ sisanya dipengaruhi oleh variabel lain yaitu Pendapatan Non Operasional.

Berdasarkan hasil Persamaan Regresinya dapat ditulis:

$\mathrm{Y}=\mathrm{a}+\mathrm{bX}$ atau $\mathrm{Y}=11703,617+0,457 \mathrm{X}$

Koefisien b disebut sebagai koefisien arah regresi, yang menunjukkan perubahan rata-rata variabel Y (Laba Bersih) untuk setiap perubahan satuan dari Variabel X (Pendapatan Operasional). Perubahan akan positif (menambah) jika b bertanda positif, sebaliknya perubahan akan negatif (menurun) jika $b$ bertanda negatif. Penjelasan dari persamaan di atas:

a Jika konstanta sebesar 11703,617 dan jika nilai X (Pendapatan Operasional) 0 , artinya tidak ada Pendapatan Operasional, maka dapat dikatakan nilai Laba Bersih sebesar Rp. $11703,617$.

b Koefisien regresi X sebesar 0,457 menyatakan bahwa setiap penambahan satuan nilai Pendapatan Operasional akan memperoleh Laba Bersih 0,457.

Berdasarkan perhitungan uji t untuk Pendapatan Operasional memiliki nilai sebesar 3,307 dan nilai signifikannya $0,030<0,05$, maka Ho ditolak dan $\mathrm{H} 1$ diterima. Ini menjelaskan ada pengaruh signifikan (nyata) variabel Pendapatan Operasional terhadap variabel Laba Bersih.

\section{KESIMPULAN}

Berdasarkan uji statistik bahwa variabel Pendapatan Operasional berpengaruh ter- 
hadap Laba Bersih di Bank Muamalat Indonesia Tbk. Periode 2015-2020, didapatkan nilai korelasi atau hubungan (R) sebesar 0,856 (Sangat Kuat), dan nilai Koefisien Determinasi atau R Square sebesar 0,732 dengan kata lain pengaruhnya $73,2 \%$, artinya variabel $X$ (Pendapatan Operasional) berpengaruh terhadap variabel Y (Laba Bersih) di Bank muamalat Indonesia Tbk. Sedangkan sisanya 26,8\% ditentukan oleh variabel lain yang tidak diteliti oleh peneliti yaitu Pendapatan Non Operasional.

\section{DAFTAR PUSTAKA}

Hartini, T. (2016). Pengaruh Biaya Operasional Dan Pendapatan Operasional (Bopo) Terhadap Profitabilitas Bank Syariah Di Indonesia. I-Finance: A Research Journal on Islamic Finance, 2(1), 20-34.

Juliandi, A., Irfan, \& Manurung, S. (2014). Metodologi Penelitian Bisnis Konsep dan Aplikasi (F. Zulkarnain (ed.); 1st ed.). UMSU PRESS.

Kartini, T. (2017). Pengaruh Pendapatan Usaha dan Biaya Operasional Terhadap Laba Bersih (Pada Perusahaan Jasa Subsektor Hotel, Restoran dan Pariwisata Yang Terdaftar di Bursa Efek Indonesia Periode 2011-2015). Manajemen Dan Bisnis (Almana), 1(2), 63-76.

Manda, G. S. (2018). Pengaruh Pendapatan dan Biaya Operasional terhadap Laba Bersih (studi kasus pada Perusahaan Manufaktur Sektor Industri Dasar dan Kimia yang terdaftar di BEI periode 2012-2016). Eqien: Jurnal Ekonomi Dan Bisnis, 5(1), 19-33. https://doi.org/10.34308/eqien.v5i1.11

Marimin, A., \& Romdhoni, A. H. (2017). Perkembangan Bank Syariah Di Indonesia. Jurnal Ilmiah Ekonomi Islam, 1(02), 75-87. https://doi.org/10.29040/jiei.v1i02.30

Nalsal, P., \& Widyawati, Y. (2015). Pengaruh Biaya Operasional Terhadap Laba Bersih Pada Bank Swasta Yang Terdaftar Di Bei. Jurnal Studia, 3(3), 127-136.

Nurbatresia, N. L. (2021). Pengaruh Pendapatan Operasional dan

Pendapatan Non Operasional terhadap

Laba Bersih PT Bank Muamalat Indonesia Tbk. IAIN Tulungagung.

Pasaribu Masdiana, A. (2017). Pendapatan Usaha dan Beban Operasional Terhadap Laba Bersih Pada Perusahaan Makanan dan Minuman. Jurnal Wira Ekonomi Mikroskil, $\quad 7(2), \quad$ 173-180. https://www.mikroskil.ac.id/ejurnal/inde x.php/jwem/article/view/501

Pasca, Y. D. (2019). Pengaruh Pendapatan Usaha dan Biaya Operasional terhadap Laba Bersih Survey pada Perusahaan Jasa Sub Sektor Transportasi yang Terdaftar di Bursa Efek Indonesia. 4(9), 163-173.

Pratama, A. W. (2018). Pengaruh Jumlah Pendapatan Operasional Setelah Distribusi Bagi Hasil dan Beban Operasional Lainnya terhadap Laba Tahun Berjalan Setelah Pajak Bersih pada PT Bank Muamalat Indonesia. UIN Sunan Gunung Djati.

PSAK No. 23. (2018). Pernyataan Standar Akuntansi Keuangan 23. PSAK No. 23, $23,1-14$.

Rachman, D., \& Putri, A. T. F. (2019). Pengaruh Deposito Mudharabah dan Pendapatan Operasional terhadap Laba Bersih pada BPRS Al-Ihsan Bandung Periode 2013 - 2017. Jurnal Ilmiah Akuntansi, 10(Januari-April), 74-89.

Rahmawati, L., \& Kosasih, K. (2020). Pengaruh Pendapatan Usaha Dan Biaya

EKSISBANK (Ekonomi Syariah dan Bisnis Perbankan), Volume 5, Nomor 2, Desember 2021 
Operasional Terhadap Laba Bersih Pada Perusahaan Manufaktur Sub Sektor Logam Dan Sejenisnya Yang Terdaftar Di Bursa Efek Indonesia Periode 20142018. Jurnal Ilmiah Mahasiswa Ekonomi Manajemen, 5(4), 834-844.

Rohmatin, A. A. (2015). Pengaruh Beban Operasional Pendapatan Operasional dan Rasio Kecukupan Modal terhadap Pertumbuhan Laba Bersih PT Bank Muamalat Indonesia. IAIN Tulungagung.

Romdhoni, A. H., \& Yozika, F. El. (2018). Pengaruh Pembiayaan Mudharabah, Musyarakah Dan Ijarah Terhadap Profitabilitas Bank Muamalat Indonesia. Jurnal Ilmiah Ekonomi Islam, 4(03), 177. https://doi.org/10.29040/jiei.v4i03.314

Rozali, kezia . C. M., \& Tjondro, E. (2013). Perlakuan Akuntansi Atas Pendapatan Dari Kredit BPD " $X$ ” Kantor Cabang Utama Surabaya. 3(2).

Sa'diya, H., Maslichah, \& Afifudin. (2019). Pengaruh Pendapatan Usaha dan Beban Operasional terhadap Laba Bersih pada Perusahaan Tekstil dan Garmen yang Terdaftar di Bursa Efek Indonesia Periode Tahun 2013-2017. E-Jra, 08(10), 56-67.

Sugiyono. (2015). Metode Penelitian Kuantitatif, Kualitatif dan $R \& D$ (22nd ed.). Alfabeta.

Suhaemi, U., \& Hasanuh, N. (2021). Pengaruh Pendapatan Usaha dan Biaya Operasional terhadap Laba Bersih. Angewandte Chemie International Edition, 6(11), 951-952., 35-40.

Supeno, W. (2019). Analisis Efisiensi BOPO Terhadap Laba Bersih Pada BPR. Jurnal Kajian Ilmiah, 19(2), 182-194. http://jurnal.ubharajaya.ac.id/index.php/ kajian-ilmiah/article/view/460
Suryadi, N., Mayliza, R., \& Ritonga, I. (2020). Pengaruh Inflasi, Biaya Operasional Terhadap Pendapatan Operasional (Bopo), Dan Pangsa Pasar Terhadap Profitabilitas Bank Umum Syariah Di Indonesia Periode 2012-2018. Jurnal Tabarru': Islamic Banking and Finance, 3(1), 1-10. https://doi.org/10.25299/jtb.2020.vol3(1) .4724

Ummah, F. K., \& Suprapto, E. (2013). FaktorFaktor Yang Mempengaruhi Profitabilitas Pada Bank Muamalat Indonesia. Jurnal Ekonomi Dan Kewirausahaan, 13(2), 100-115. http://muqtasid.iainsalatiga.ac.id/index.p $\mathrm{hp} /$ muqtasid/

Wahyuni, S. F. (2016). Pengaruh Loan to Deposit Ratio (LDR), Capital Adequacy Ratio (CAR) dan Rasio Beban Operasional Pendapatan Operasional (BOPO) terhadap Return on Assets (ROA) pada Perbankan yang terdaftar di Bursa Efek Indonesia. JURNAL AGRICA, 9(1), 29-37.

Wida, O., Zakaria Hakim, H. M., \& Huda, S. (2019). Pengaruh Non Performing Loan Dan Biaya Operasional Pendapatan Operasional Terhadap Laba Bersih. AKTSAR: Jurnal Akuntansi Syariah, 2(1), 135. https://doi.org/10.21043/aktsar.v2i1.528 2

Winarto, H., \& Nuraisyah, E. (2019). Analisis Pengaruh Pendapatan Margin Murabahah dan Pendapatan Bagi Hasil Musyarakah terhadap Laba Bersih PT Bank Negara Indonesia Syariah (Periode Tahun 2012 2018). Jurnal Akuntansi Dan Bisnis Krisnadwipayana, 6(3), 64-71. https://doi.org/10.35137/jabk.v6i3.324

Wulandari, M. A. (2017). Pengaruh 
Pendapatan dan Biaya Operasional terhadap Laba Bersih Studi Kasus pada PT. Garuda Indonesia Tbk. Jurnal Akuntansi, Audit Dan Sistem Informasi Akuntansi, 1(4), 1-15. 